Original Research Paper

\title{
Worker's Representation: Foreign Practice and the Prospects for Reforms in the Republic of Kazakhstan
}

\author{
Yenlik Nurgalyevna Nurgaliyeva and Muslim Khanatovich Khassenov \\ Faculty of Law, L.N.Gumilyov Eurasian National University, 2 Satpayev St., 010000 Kazakhstan, Astana, Kazakhstan
}

Article history

Received: $23-10-2015$

Revised: 07-01-2016

Accepted: 08-01-2016

Corresponding Author:

Muslim Khanatovich

Khassenov

Faculty of Law, L.N.Gumilyov

Eurasian National University,

2 Satpayev St., 010000

Kazakhstan, Astana,

Kazakhstan

Email: atamekenlaw@gmail.com

\begin{abstract}
The article deals with the problems and the ways to reform the institution of employee representation in the context of a social partnership model in Kazakhstan. The scientific-theoretical and practical grounds for institution of worker representation are analyzed. The foreign experience in organizing a social partnership using continental Europe as an example (particularly Austria and Germany) is studied. The authors make a conclusion about the necessary measures to improve the institution of worker representation. Taking into consideration the Republic of Kazakhstan's transition to the continental business community model, the optimal model of social partnership for Kazakhstan is an Austrian model based on equal social partners' functioning, i.e., economic chambers or the chambers of entrepreneurs and labor chambers. To guarantee a balance of interests between employers and workers in the Republic of Kazakhstan, it is necessary to establish a Republican labor chamber on the basis of an independent act with a mandatory membership of all the employees of organizations-members of the National Chamber of Entrepreneurs of the Republic of Kazakhstan. When implementing the above model, the system of trade unions representing industrial and professional interests of employees should be preserved on a voluntary basis.
\end{abstract}

Keywords: Representation, Workers, The Austrian Model, The Republican Chamber of Labor, Social Partnership

\section{Introduction}

The institutional structure of the society is a framework on which the entire political, economic and social system is based.

Understanding this, President of the Republic of Kazakhstan N.A. Nazarbayev proposed a "non-standard response to global challenges of Kazakhstan's statehood in his speech in March 2015. Five institutional reforms were suggested (Nazarbayev, 2015).

They include the formation of modern, professional and autonomous government machine; the provision of the supremacy of statute law, the guarantee of ownership interests, which creates the conditions for entrepreneurial activity; industrialization and economic growth based on diversification; the national identity formation; the formation of transparent and accountable State.

In the context of the problem under study we consider a more extensive self-regulation of the society to be a key necessity. "It is required to reduce the areas of responsibility of public authorities by delegating power to civil society institutions" (Nazarbayev, 2015).
In this regard, we believe that now there is a long overdue need to reform the institution of employee representation, which will allow compensating the balance of interests of labor and capital and to apply the positive experience of interaction between the State and the civil society institutions (for example, the National Chamber of Entrepreneurs of Kazakhstan) to the most sensitive sphere-the sphere of labor.

We presume that the above institutional reform will be one of the basic conditions of sustainability and stability of the entire social structure of the society.

\section{Methodology}

In preparing this study, the authors used a comparative law, structural-functional and legal modeling methods.

Owing to the comparative law method the authors formed a complete picture of the employee representation institution functioning in the Republic of Kazakhstan and foreign countries, the legal conditions for its reformation at different stages of its development. 
The structural-functional method allowed us to identify the key characteristics of the institute of worker representation as an integral part of the social partnership system, the main trends in the development of this institution with its inherent functions and activities.

The legal modeling method enabled the authors to consider the mechanism of employee representation in dynamics and to identify the key aspects of its relationship with other institutions (including the employers' and the state representation).

\section{Results}

Reformation of the mechanism for representation of the workers' interests in the system of social partnership requires institutional prerequisites available.

A serious institutional framework, which represents the country's employers, is established in the Republic of Kazakhstan nowadays. In July 2013, the Law of the Republic of Kazakhstan "On the National Chamber of Entrepreneurs of Kazakhstan" was adopted. It was the first law in the post-Soviet area judging by its content and its formalized mechanism.

In accordance with the above Law, in September 2013 the National Chamber of Entrepreneurs of the Republic of Kazakhstan was established, which is both a non-profit organization and a legal entity carrying out public nongovernment functions (RK Law No. 129-V, 2015).

The need for establishing the National Chamber of Entrepreneurs was dictated by the lack of consolidation within the business community and the low efficiency of institutional representation of a unified position of business to protect their legitimate rights and interests at the state level.

The formation and activity of the National Chamber of Entrepreneurs is carried out by means of compulsory membership of entrepreneurs on the basis of the relevant law in order to strengthen the interaction of business and authorities. The National Chamber consists of all business entities (both private and state ones), except for the state-owned enterprises and organizations of evaluators and auditors (as they have already been legally prescribed for professional organizations of evaluators and auditors, respectively) (RK Law No. 304-I, 2015).

In this regard, on the background of enhanced positions of the employers represented by the largest organization-the National Chamber of Entrepreneurs, a situation arises, resulting in an imbalance of legal opportunities between representatives of employers and workers.

The provisions of the law of the Republic of Kazakhstan "On Regulatory Legal Acts" (art. 14) are a vivid legal evidence of this imbalance, they provide preferential position of employers' representatives, acting through the National Chamber of Entrepreneurs of the Republic of Kazakhstan and accredited associations of private businesses as to the representatives of workers:

1. The authorized body, which develops the draft of the regulatory legal act, creates a working group to prepare a draft or delegates its preparation to one of its divisions, which performs the functions of the working group... It is mandatory for the representatives of the National Chamber of Entrepreneurs in the Republic of Kazakhstan and accredited associations of private businesses to participate in the development of regulatory legal acts affecting the interests of private businesses.

2. Specialists in different fields of knowledge, scientific institutions and scientists, representatives of public associations may be involved in the preparation of draft laws, regulatory legal acts of the President of the Republic of Kazakhstan, regulatory legal resolutions of the Government of the Republic of Kazakhstan and, if necessary, drafts of regulatory legal acts of other authorized bodies" (RK Law No. 213-I, 2015).

Thus, the participation of representatives of public associations, which could include trade unions (authors' notes-under article 2 of the Law "On Public Associations", trade unions are public associations in their organizational and legal form (RK Law No. 3-I, 2015 ) is optional, while the participation of employers' representatives (on matters affecting the interests of private businesses) is mandatory.

Another manifestation of the imbalance is the general weakness of trade unions in protecting the interests of workers. We also agree with N. Kasiliauskas in this respect, who associates the negative assessment of the trade union activities with the fact that they overindulge, for example, in political activity and it has nothing to do with the implementation of employees' rights and interests, so the activity of trade unions in this fundamental sphere of their activity is reduced (Kasiliauskas, 2009).

Of course, in Kazakhstan, trade unions are not so deeply involved in politics, but the presidential elections which took place in April 2015 in the Republic of Kazakhstan clarified the level of perception by the population of the trade unions' importance and activities. Thus, out of 3 candidates for the highest political office in the Republic of Kazakhstan the lowest number of votes was received by the Chairman of the Trade Union Federation which is less than $1 \%$ of the votes $(0.7 \%)$. In comparison, the candidate from the Communist People's Party got twice as many votes- $1.6 \%$.

\section{Discussion}

The authors consider it necessary to elaborate institutional and legal measures to reform the institution of worker representation in Kazakhstan, based on the experience of some foreign countries. 


\section{The Institution of Worker Representation}

The doctrinal level has not had a unified position so far on the legal nature of the institution of representation in labor law.

Some authors claim that there are no serious reasons for the formation and development of the institution of representation in the labor law, as in the civil law, since the labor relationship in law does not admit the possibility of replacing actors. Concerning the relationship of social partnership, the participation of workers and trade unions in establishing the working conditions and application of labor legislation, in this case it is not representation involved, but the delegation of authority by the employer, employees (workers' association) and other public and professional organizations (Lebedev, 2002).

Other authors believe that the category of representation is known only in civil, criminal and international law, in civil and arbitration processes (Isaienko, 1999).

We cannot agree with the above positions, because in reality the institution of representation takes place in the socio-labor relations; it emerged and is developing along with the other institutions of labor law.

Within this framework we share the opinion of V.M. Dogadov, who said as early as in the first half of the 20th century: "Apart from the title, the trade union representation has nothing in common with representation in the sphere of civil relations" (Dogadov, 1928).

The institution of representation in labor law, according to V.A. Vasiliev, is a set of interrelated legal regulations governing the workers' representation (workers' unions) and the representation of employers (employers' unions) in labor relations (Vasiliev, 2006).

The Kazakh legislator determines in article 1 (subclause 40, clause 1) of the Labor Code of the Republic of Kazakhstan that individuals or legal entities represent the interests of the employer, within their delegated authority based on the constituent instruments or power of attorney (Labor Code, 2015). Moreover, the range of workers' representatives is clearly formalized (subclause 44, clause 1 of Article 1 of the Labor Code of the Republic of Kazakhstan) - trade union bodies, their associations and, in their absence, the elective representatives who are elected by a majority of votes and authorized by the employees at the general meeting (conference) of employees in case no fewer than two thirds of employees (conference delegates) are present.

This definition complies with international labor standards, according to which representatives of trade unions and other elected representatives of the employees shall be regarded as workers' representatives. The activity of other workers' representatives is governed by the ILO Convention (No. 135) concerning protection and facilities to be afforded to workers' representatives in the undertaking (Geneva, June 23, 1971), ILO Workers' Representatives Recommendation (No. 143). However, Convention No. 135 establishes that the exclusive prerogative of trade unions relating to solution of a number of social and labor issues cannot be replaced by functions of other representative bodies and thus protects the special status of trade unions in the field of labor law (Convention No. 135, 2015).

Referring to the Convention, the importance of its provisions should be noted. Thus, article 2 largely separates and balances the interests of employees and employers: "1. Such facilities in the undertaking shall be afforded to workers' representatives as may be appropriate in order to enable them to carry out their functions promptly and efficiently. 2 . In this connection account shall be taken of the characteristics of the industrial relations system of the country and the needs, size and capabilities of the undertaking concerned. 3 . The granting of such facilities shall not impair the efficient operation of the undertaking concerned." The significance of this article, according to Professor Y.N. Nurgalieva, is in distinguishing facilities of different employers. Such giants as big oil companies and other industry leaders can afford incomparably greater amount of guarantees in the field of remuneration and social benefits, rather than the owners of old worked-out deposits, small processing plants, etc. Consequently, the rights and duties of these various types of employers must be different.

Minimum guarantees of workers' rights established under the legislation must be observed by everyone. As to the additional guarantees, they are set forth at a collective-contractual level. Articles 4-5 distinguish between the notions of "union representatives" and "elected representatives", i.e., representatives of labor collectives, whose activities are not connected with that of trade unions. The significance of article 5 is that it prohibits the elected representatives from engaging in trade union activities (Nurgaliyeva, 2009).

The International Covenant on economic, social and cultural rights dated December 16, 1966 secured the right of trade unions to function freely without any restrictions except those which are provided by the law. In its turn, the Law of the Republic of Kazakhstan of June 27, 2014 "On Trade Unions" provides the rights of trade unions to represent and protect the rights and interests of their members, as well as to act as workers' representatives in relations with public authorities within the scope of their authority, employers, associations of private business entities (alliances, unions), other public organizations; bring a case before a court to protect the rights and interests of its members, to speak on their behalf in conducting mediation, in court, labor arbitration or arbitration tribunal, in state bodies, to provide them with other legal aid and to exercise other rights (RK Law No. 211-V, 2015) 
Considering the legal status of trade unions, it is necessary to understand their dual character.

On the one hand, there is danger that they shall monopolize the labor market, which will allow trade unions to raise wages primarily for their members. On the other hand, trade unions represent and protect the interests of all employees through collective agreements and thereby play an important social role (Sannikov, 2005). Therefore, the vast majority of scientists, in our view, are right to believe that currently only the trade unions are able to effectively represent and protect the interests of employees, rather than the other workers' representatives (Nurgaliyeva, 2010).

In this regard, we fully agree with the authors like D. Petrylaite and N. Kasiliauskas concerning the legal nature of trade unions, who believe that trade unions are not only representatives, but also independent subjects of the labor relations (Petrylaite, 2005).

Trade unions as members of collective labor relations, first of all, represent the interests of workers. For such representation Lithuanian lawmaker approved the general principle of representation: In this sphere, trade unions represent the interests and rights of manpower population, regardless of the workers' membership in the trade union. At the same time in relation to the state institutions, other trade unions, employers' organizations trade unions act on their behalf, so trade unions are not only representing the employees, but act as independent subjects of labor relations.

In the sphere of individual labor relations trade unions represent only their members (the principle of a special representation). But at the request of the employee who does not belong to the trade union, they can take on representation of the rights and interests of such an employee (Kasiliauskas, 2009).

The above principles of general and special representation are accepted by the legislator in the updated version of the Labor Code (article 156): "Workers who are not members of a trade union, on a contractual basis have the right to authorize a trade union body and other representatives to represent their interests in relations with the employer. In the presence of several workers' representatives in the organization they create a unified representative body for them to participate in the commission and signing of a collective agreement" (Labor Code, 2015).

\section{Foreign Experience in the Regulation of the Legal} Status of Social Partners

Taking into account the special nature of the social order in the Republic of Kazakhstan, its increasing attraction to the so-called neo-corporatism, we consider a number of key characteristics of the legal status of social partners in the states that are built on neo-corporate ideology.
Corporatism is defined as a form of social organization in which the key economic, political and social decisions are made by corporate groups or jointly by these groups and the state (Abercrombie et al., 1997). According to this concept, individuals can influence the decisions made at the state level through the membership in the corporate bodies, i.e., trade unions, professional organizations, business associations, political pressure groups and lobbies, voluntary associations (Krivosheiev, 2004).

What appeals to us greatly is the experience of the so-called "liberal" corporatism or neo-corporatism, in particular, in the Austrian system of social partnership. It should be borne in mind that some elements of social order concept are inherent in almost every Western European country and in general in states with prevailing political pluralism.

Austria is a classic example of neo-corporatism which set the pattern for imitation in other countries. In the Austrian political system parliamentary "competitive democracy" coexists with neo-corporate "democracy of consent". The parities' representatives who are elected by direct vote compete at the first level; at the second level representatives of associations try to reach an agreement. The decision-making processes are intertwined due to diverse institutional and personal relations between the two levels. However, the system of social partnership remains autonomous in relation to the Parliament (Tradition, 2015).

One of the most important and unique features of this system is the so-called institution of obligatory membership in the Chambers, which is known in the world practice in terms of organizing the business community and workers' teams. Thus, the so-called continental model of social organization is the most widespread in the world. It has been applied successfully in Germany, France, Italy, Spain, the Netherlands, Greece, Austria, Turkey and other countries (Pilgrim and Meier, 1995).

For example, membership in the German Chambers of Commerce is mandatory for all self-employed individuals and legal entities engaged in business, including entrepreneurs, industry and trade companies. There exist separate chambers for agriculture, small businesses and professionals such as lawyers, doctors and architects. It is compulsory to have a membership for all companies listed in the commercial register in the French Chambers of Commerce. This register includes companies of industrial, commercial and professional sectors.

According to the continental model, the Chambers are established on the basis on the national law. The law on Chambers provides the establishment of chambers as corporations under the public law. This legal status allows the government to delegate certain functions to 
the Chamber, which usually belong to the public authorities (for example, education, expertise and business registration).

A unique aspect about the continental model is that the Chambers are obliged to perform certain functions enshrined in the law. The state delegates some of its functions to the Chambers, taking into account their close links with the business community.

Thus, the key provision for the chambers' activities as legal entities carrying out public functions is the establishment by the state of a number of authorities which are traditionally carried out by government bodies.

Austria is a striking example of the balance within this model, where strong chambers of workers (represented by the Federal Chamber of Labor and its Land Chambers) resist strong Chambers of entrepreneurs (represented by the Federal Economic Chamber and its Land Chambers).

As researchers impartially highlight, an important factor in the formation of social market economy was partner relations between labor and capital in the postwar Austria. The Federal Chamber of Labor, which appeared in 1920, significantly expanded its competence after the war. It included all employed Austrians, both public officers and private enterprise employees. Similar chambers united farmers, selfemployed professionals, traders, small businessmen and big industrialists. According to the laws, being currently in force, the Federal Chambers were established for expressing the interests of its members and working out a strategy of economic development for the whole country (Vatlin, 2014).

At present, the Austrian Chamber of Labor represents the interests of 3.4 million employees and consumers in the country. Describing the current state of Australian Chamber of Labor, let us consider its key objectives (AFCL, 2015):

a) Conducting the basic research in the interests of the welfare of workers and consumers;

Chamber of Labor's personnel includes highly qualified experts and is organized as "think tank" for the workers' interests.

b) Participation in the monitoring and control of the legislative process;

The Chambers carry out expert evaluation of proposals for legislative acts in the context of the workers' interests. They make proposals to amend the legislation and accordingly take part in the implementation of the statutory provisions.

c) Rendering of services to their members, including the provision of information and advice on issues such as labor law, social security, tax law, family law, health and safety, consumer protection, protection of the rights of women and young workers, protection against unemployment.
The Chambers provide legal support to workers by protecting their interests in the process of resolving labor disputes in the courts about the socio-labor issues. Training and professional improvement of the labor movement officials, organization of fairs and exhibitions, arrangement of cultural and leisure activities hold a significant place in the activities of the Chambers.

d) International representation.

At the European level, the Chamber of Labor delegates its representatives in the Economic and Social Committee and other consultative and advisory bodies.

Analyzing the structure of the Chambers, it should be mentioned that the Federal Chamber is an "umbrella organization" uniting the Chamber of Labor, located in 9 lands of Austria according to the federal structure of the Republic. Federal and regional Chambers are selfregulated public corporations (Note 1).

Considering the peculiarities of membership in the Chamber, it must be stressed that compulsory membership applies to all employees, as well as the unemployed, except for the public officials and agricultural workers (Note: Along with the Chamber of Labor there is a Chamber of Agriculture operating in Austria with a compulsory membership of all agricultural workers). The Chamber represents the interests of retired workers, as well.

The institutional structure of the Chambers is formed by means of election form "the bottom upwards": The General Assemblies, operating in each regional Chamber (the so-called "Parliament of workers and employees") are elected on the basis of equal, direct and secret ballot for a period of 5 years. The executive body of the Chambers is the Board which is headed by the President.

The financial basis for the entire structure above is based on the so-called labor charge, accounting for approximately $0.5 \%$ of the total wages of all members or maximum salary value.

However, Chamber of Labor is not the only organization representing the interests of workers in Austria. Trade unions with voluntary membership act along with it.

Founded in 1945, the Austrian Trade Union Federation (ÖGB) is the only organization representing the interests of the employees on the basis of voluntary membership, consisting of 16 sectoral trade unions. As well as the Chamber of Labor, Trade Union Federation is responsible for participation in the drafting of new laws. It prepares political reviews and the proposals for draft laws submitted by other organizations, which are later taken into account in the course of decision-making. Trade unions promote the conclusion of collective agreements at a sectorial level. Moreover, the Trade Union Federation regulates issues such as working hours, holidays and Christmas bonuses, overtime payment, wage increases. Trade union members have the 
right to get legal advice and representation in court, as well as many other benefits (ATUF, 2015).

However, there is a reasonable question about the delimitation of jurisdiction between the Chambers of Labor and Trade Unions. The Chambers of Labor do not interfere with the process of collective bargaining, conclusion of collective agreements and sector regulation of employees' activities (this is an exclusive competence of the Trade Union Federation). The Chambers of Labor deal with the issues of employment and social policy at the state (federal and regional) level and represent the interests of workers in the courts (Rebhahn, 2012).

Considering the fact that the above organizations do not only represent the interests and provide services to its members as social partners, but they are also involved in the Austrian political system in different ways, it is appropriate to classify such system from the view point of the political regime. Some authors refer Austria to the German social democracy model, one of its features being the constructive role played by various social forces in the development of production and the economy as a whole, in the elaboration and adoption of socially significant decisions in accordance with the task of creating a "Labor Community of Tomorrow" (Krasinskiy, 2008).

To confirm the feasibility and viability of the Austrian model perception, we share the conclusion of R. Knaak, according to whom "in order to ensure the flexibility of the economy and its quick adaptation to changes considerable decentralization is necessary, while development in the long term requires stability and maintaining the overall structure of established economic links" (Knaak, 1994).

For this very reason "in the 21 st century Austria remains a democratic state which develops based on the principles of social partnership and a well-considered compromise" (Vatlin, 2014).

\section{Reforming the Mechanism for Representation of Workers' Interests in the System of Social Partnership in the Republic of Kazakhstan}

Prior to proceed to consideration of the issue on reforming the mechanism for representation of workers' interests, it is very important to dwell upon the notion of the balance of interests.

Pyankova (2014) suggested that the balance of interests of the parties to legal relations should be understood as such state of legal relations when the rights and obligations of the parties are proportionate and the parties have equal opportunities for realization of their legitimate interests.

Haliulin (2009) indicates that theoretically, the notion of balance of interests between legal entities is defined as a special condition enshrined in the law, that is an optimal life activity mode of the State, the civil society and the individual expressing the accountancy and the objectively required ratio of legally significant interests of the subjects of law, aimed at creating the appropriate legal environment for their favorable development and secured by the opportunity of state legal impact.

Didenko (2013) includes the balance of interests into the list of evaluative concepts, which can be found in the civil law and relate to the widest range of civil legal institutions.

In any case, according to the various and often not numerous views of jurists, result in a common denominator that balance of interests is the ultimate objective and acceptable outcome of harmonization (Zhakupov and Khassenov, 2014).

Thus, the key condition for the balance of interests is adequacy and proportionality in the ratio of means and methods by which the interests of employers and employees are represented, i.e., proportionality of the institutional framework of the employers and employees' associations.

\section{Conclusion}

Taking into account the transition of the Republic of Kazakhstan to the continental business community organization model, the optimal model of social partnership for Kazakhstan is an Austrian one, which is based on functioning of equal social partners: Economic Chambers or Chambers of Entrepreneurs (authors' noteNational Chamber of Entrepreneurs of the Republic of Kazakhstan has been operating since September 2013) which bring together all business entities and Chambers of Labor, uniting all the workers engaged in labor activity in the organizations-members of the economic Chambers (Chambers of Entrepreneurs).

In order to provide the balance of interests between employers and employees in the Republic of Kazakhstan, the Republican Chamber of Labor should be established on the basis of separate law with compulsory membership for all employees of the organizationsmembers of the National Chamber of Entrepreneurs of the Republic of Kazakhstan.

While implementing the above model the system of voluntary trade unions, representing sectorial and professional interests of employees should be preserved (authors' note-similarly as nowadays the system of entrepreneurs and employers' associations with voluntary membership is preserved on a sectorial basis).

The proposed reform will allow preventing and avoiding a future process of merger between the state and business structures and their interests, the occurrence of which is natural under the conditions of the increasing close interaction between organizations 
that bring together the business community and public authorities (officials who make policy decisions).

\section{Acknowledgment}

The authors express their gratitude to L.N. Gumilyov Eurasian National University for the opportunity to undertake this study in the framework of the State educational grant for doctoral studies of $\mathrm{PhD}$ M.Kh. Khassenov (2013-2016), as well as for the possibility to carry out academic advising of the doctoral candidate on the part of Doctor of Laws, Professor E.N. Nurgaliyeva.

\section{Funding Information}

This work was financially supported by L.N. Gumilyov Eurasian National University.

\section{Author's Contributions}

Yenlik Nurgalyevna Nurgaliyeva: Designed the research plan and coordinated the data analysis.

Muslim Khanatovich Khassenov: Analyzed foreign practice, collect data and contributed to the writing of the manuscript.

\section{Ethics}

This article is original and contains unpublished materials. The authors have no conflict of interests in the development and publication of the current research.

\section{References}

Tradition, 2015. Encyclopedia, Official website.

Abercrombie, N., S. Hill and B. Turner, 1997. Dictionary of Sociology. 1st Edn., The University of Kazan Press, Kazan, ISBN-10: 5-282-02334-2, pp: 130.

AFCL, 2015. Austrian federal chamber of labor. Official website.

ATUF, 2015. Austrian trade union federation. Official website.

Convention No. 135, 2015. Workers' Representatives Convention (Entry into force: 30 June, 1971).

Didenko, A.G., 2013. The theory of civil law: Challenges of time. Almaty.

Dogadov, V.M., 1928. The legal status of trade unions in the USSR (Essays on trade union rights). Leningrad.

Haliulin, V.E., 2009. Coordination of interests of subjects of law as a prerequisite for the formation of civil society in the Russian Federation. PhD Thesis, Saratov.

Isaienko, S.V., 1999. Representation in labor law. Legal problems of strengthening the Russian statehood. Tomsk, 42: 253-255.
Kasiliauskas, N., 2009. The Problems of legal personality of trade unions in labor relations. Theoretical problems of the Modern Labor Law and Social Security Law: National and International Aspects. Proceedings of the International Conference Information Package, Jun. 26-27, Vilnius, pp: 174-174.

Knaak, R., 1994. Social partnership: The Western experience. Questions Economy, 5: 92-92.

Krasinskiy, V.V., 2008. History and prospects of European socialism. Politics and Society. Lipetsk Publishing House.

Krivosheiev, V.T., 2004. Social partnership and corporatism: Russian specificity. Sociological Res., 6: $38-44$.

Labor Code of the Republic of Kazakhstan dated November 23, 2015. Information system "Adilet.

Lebedev, V.M., 2002. Lektsii Po Trudovomu Pravu [Lectures on labor law]. 1st Edn., Tomsk State University Publications, Tomsk, ISBN-10: 5-7511-1405-1, pp: 51.

Nazarbayev, N.A., 2015. Speech at the XVI Regular Congress of the Party "Nur Otan". Official website of the President of the Republic of Kazakhstan.

Nurgaliyeva, E.N., 2009. Comments on the Labor Code of the Republic of Kazakhstan. Almaty: ZhetyZhagry. ISBN 9965-11-306-8

Nurgaliyeva, E.N., 2010. Authority of workers' representatives in the sphere of social and labor relations. L.N. Gumilyov Eurasian National University, Astana.

Petrylaite, D., 2005. Collective labor disputes. Vilnius.

Pilgrim, M. and R. Meier, 1995. National chambers of commerce: A primer on the organization and role of chamber systems. Center for International Private Enterprise (CIPE).

Pyankova, A.F., 2014. The concept of balance of interests and its place in civil law of Russia. Bulletin of Perm State University.

Rebhahn, R., 2012. Austrian Labor Law and Labor Relations as a Pattern of Flexibility. Labor Regulation in the 21st Century: In Search of Flexibility and Security. Tomas Davulis and Daiva Petrylaite (Eds.), Newcastle, UK: Cambridge Scholars.

RK Law No. 3-I, 2015. The Law of the Republic of Kazakhstan "On Public Associations" dated May 31, 1996. Informational system "Adilet".

RK Law No. 129-V, 2015. The Law of the Republic of Kazakhstan "On the National Chamber of entrepreneurs of the Republic of Kazakhstan" dated June 4, 2013. Informational system "Adilet".

RK Law No. 211-V, 2015. The Law of the Republic of Kazakhstan "On Trade Unions", dated June 27, 2014. Informational system "Adilet".

RK Law No. 213-I, 2015. The Law of the Republic of Kazakhstan "On Regulatory Legal Acts", dated March 24, 1998. Informational system "Adilet". 
RK Law No. 304-I, 2015. The Law of the Republic of Kazakhstan "On Audit Activity" dated November 20, 1998. Informational system "Adilet".

Sannikov, N.M., 2005. Trade union security as a means of ensuring freedom of association. Russian Annual of Labor Law.

Vasiliev, V.A., 2006. Representation in labor relations. Employment Law.

Vatlin, A.Y., 2014. Austria in the XX century: A textbook for high schools. Moscow-Berlin: DirectMedia.

Zhakupov, R.E. and M.K. Khassenov, 2014. Social partnership at work: Regulatory framework and balance of interests. Astana, 4: 138-146.

Zhakupov, R.E. and M.K. Khassenov, 2013. On the legal status of legal entities carrying out public functions. Proceedings of the International Conference Information Package in the Context of Annual Civil Readings Dedicated to the 90th Anniversary of the Outstanding Kazakh Civil Law Scholar, May 13-14, Almaty, pp: 334-343.

\section{Notes}

It is necessary to distinguish between the public functions and the state ones. State functions are performed by the organs of state power and administration. The state as a sovereign determines which functions can belong to a government body and which (in accordance with the Constitution and on the basis of regulatory legal acts only) refer to the competence of such entities.

In this regard, it is quite reasonable that other entities cannot have state functions, except the state. But while getting these functions completely out of the government sector, they do not lose their important value for society and for this reason they are called public. It is obvious that the state must necessarily outline public functions of such entities in legal acts (such as a regulatory act), which, is done by the legislator, though.

(For more details see: Zhakupov and Khassenov, 2013). 